\title{
Causal Relationship between Gross Domestic Product and Agricultural Production in Libya (1970-2012)
}

\author{
Khaled Ramadan Elbeydi \\ Agricultural Economics Department - Faculty of Agriculture - University of Tripoli - Tripoli- \\ Libya
}

Corresponding author: Khaled Ramadan Elbeydi, e- mail: khaled712001@yahoo.com

\begin{abstract}
This paper is empirically investigated the causal relationships between gross domestic product and agricultural production in Libya by using annual time series data during the period (1970 to 2012). Granger causality, cointegration, and error correction techniques were used in order to determine the long run equilibrium relationship and the direction of the causality in both short run and long run.

The cointegration test indicated the existence of long run equilibrium relationship between agricultural production and the Gross Domestic Product. The causality test based on error correction techniques indicated that there is an unidirectional causality relationship between agricultural production and the Gross Domestic Product in the short run. This result means that the agricultural sector in Libya is expected to play a major role in the future to determine the growth rate of the economy with further expected development of the agricultural sector.
\end{abstract}

Keywords: Causality, Cointegration, GDP, Agricultural production, Libya

\section{INTRODUCTION}

Libya is a Northern African country located between Tunisia and Algeria on the west and Egypt on the east. The population was estimated at about 6 million in 2010 , which about $85 \%$ lives in urban areas. The population density is about a 3 persons $/ \mathrm{m}^{2}$ which is one of the lowest in the world. Although the population growth rate has been declining, it has averaged about $2.5 \%$ annually over the past 20 years. About 135,700 people work in agriculture, out of a total of 1.8 million workers. (FAO, 2011).

The currency of Libya is the Libyan Dinar (hereafter referred to as LYD), which equals 0.8 US $\$$ in 2012 . The Libyan economy began to develop when oil was discovered in 1958; Libyan economy is based basically upon revenues from the oil sector, which contributes to practically all export earnings and about one quarter of Gross Domestic Product at constant price hereafter (GDP). As shown in Table 1, the GDP in 2012 was about LYD 117 billion. With high oil revenues and small population, Libya ranks as one of the countries with the highest per capita GDP in the African continent. 
J. Adv. Agric. Res. (Fac. Agric. Saba Basha)

Table (1). Agricultural production and its contribution to the Libyan gross domestic product in million Libyan dinars during the period (19702012).

\begin{tabular}{lccccccc}
\hline \multicolumn{1}{c}{ Item } & $\mathbf{1 9 7 0}$ & $\mathbf{1 9 8 0}$ & $\mathbf{1 9 9 0}$ & $\mathbf{2 0 0 0}$ & $\mathbf{2 0 0 5}$ & $\mathbf{2 0 1 0}$ & $\mathbf{2 0 1 2}$ \\
\hline Total GDP(LYD) & 1,288 & 10,553 & $\mathbf{8 , 2 4 6}$ & 184,560 & 66,618 & 102,538 & 117675 \\
Agriculture (LYD) & 33.1 & 236.4 & 482.9 & 1437.7 & 1447.5 & 2543.6 & 928.7 \\
$\%$ of GDP & 2.6 & 2.23 & 5.9 & 7.8 & 2.2 & 2.5 & 0.78 \\
\hline
\end{tabular}

Source: Central Bank of Libya, Economic Bulletin, Research and Statistics Department, various issues.

Libyan agriculture has experienced slow growth since the 1990s and has been facing considerable challenges in recent years. The annual agricultural production has increased over the years, but the share of agriculture in the gross domestic product declined from about $2.6 \%$ in 1970 , to about $2.2 \%$ in 1980 , and it was about $0.78 \%$ in 2012 (Table 1).

The total area of Libya is about 176 million hectares; only about $1.2 \%$ is arable land, while the rest is desert. Agricultural land area was about 13 million hectares in 1970 increased to about 15 million hectares in 2010 represents about $18.6 \%$ from basic year. Permanent crop areas increased from about 327,000 hectares in 1980 to about 335,000 hectares in 2010 (18\% of total arable land). Irrigated agricultural land also increased from about 225,000 hectares in 1980 to about 470,000 hectares in 2010 (FAO, 2015). The main crop products were potatoes, tomatoes, olive, watermelons, onions and dates, oranges and barley are produced. (FAO, 2011).

According to the study of Aljdi and Elbeydi (2010) which investigate the development of the Libyan agricultural sector and its main components and the determination of both relative share of the agricultural subsectors which constitute the Libyan agricultural income, and the most important economic factors affecting the Libyan agricultural income during the period (1980-2005). The results of their study indicated that there is a significant increase in the annual rate of the agricultural production. The results of the study indicated that the most important variables affecting the Libyan agricultural income were the agricultural machine and the irrigated area. Consequently, it is recommended to carry out several empirical and economic studies to determine adequate basic needs of modern mechanical and irrigation methods to perform various agricultural operations for all agricultural activities.

The agricultural sector comprises of four major subsectors includes crops, livestock, fisheries and forestry. The largest portion of the agricultural sectoral is on account of crops and livestock with share of $71 \%$ and $28 \%$ respectively in 2005 . However, in the late 1990s and earlier, the crop sector was dominating and accounting for more than $50 \%$ of the total agricultural output. 
Libya has invested more than LYD 5 billion in the agricultural sector during the period of 1970-1990. These investments, in addition to the private sector investment, enabled the country to establish the infrastructure needed to develop the sector to a satisfactory level. During the periods of $1970-1986$, Libya had implemented three successive development plans; a three - year development plan (1973 - 1975), and two five - year development plans (1976-1980) and (1981 1985). The objectives of these plans were to ensure self-sufficiency level in food, especially wheat, which was considered the most strategic food crop.

Therefore, it is too important to explore the possible relation between agriculture and economic growth. Increasing of GDP is the main target of almost every economy, promoting agriculture of the country is one of the ways of achieving economic growth.

A strong and an efficient agricultural sector would enable a country to feed its growing population, generate employment, earn foreign exchange and provide raw materials for industries. The agricultural sector has a multiplier effect on any nation's socio-economic and industrial fabric because of the multifunctional nature of agriculture.

There are a number of real and monetary links from the agricultural sector affecting the economic performance of the general economy. These relationships often are referred to as backward linkages. Agriculture, as one sector of the economy, competes for scarce labor and capital inputs from other sectors, it provides raw materials for other sectors, it directly provides consumer needs for food and fiber, and it generates a component of national income.

Stringer and Pingali (2004) argued that investments in agriculture contribute to more than increases in production. With the proper policies and incentives, agricultural sector investments improve food security, lower rural and urban poverty, reduce inequality and enhance environmental outcomes. Economic development in general and agricultural economists in particular have long focused on how agriculture can best contribute to overall economic growth and modernization. Many early analysts highlighted agriculture because of its large quantity of resources and its ability to transfer surpluses to the more important industrial.

The conventional approach to the role of agriculture in development concentrated on agriculture's important market-mediated linkages: first, providing labor for an urbanized industrial work force, second, producing food for expanding populations with higher incomes, third, supplying savings for investment in industry, fourth, enlarging markets for industrial output, fifth, providing export earnings to pay for imported capital goods, and lastly, producing primary materials for agro-processing industries. 
Economic growth originating in agriculture can have a particularly strong impact in reducing poverty and hunger. Increasing employment and incomes in agriculture stimulates demand for non-agricultural goods and services, providing a boost to non-farm rural incomes as well. (Pingali.,2006) .

Therefore, the main focus of this study is to analyze empirically the existence and direction of Granger causality and co-integration between agricultural production and the total economy activity to help the policy makers for having a better insight into economic growth and to formulate effective economic policies.

\section{MATHERIALS AND METHODS}

The recent developments in non-stationarity and cointegration theory have contributed to a better understanding of long-run and short-run dynamics in international economics and finance. Many applications in agricultural economics research have focused on the problem of testing Granger non-causality. ( Zapata and Gil, 1999).

This study is based on three hypotheses for testing the causality and cointegration: (i) whether there is bi-directional causality between agricultural and GDP, (ii) whether there is unidirectional causality between the two previous variables, (iii) whether there is no causality between the two previous variables.

In the first stage the order of integration was tested using the Augmented Dickey-Fuller (ADF) unit root test. We assume all the series to be integrated of order 1 . If this assumption is satisfied, we try to identify the long run equilibrium relations between the integrated time series and estimate short run equations. Granger (1988) shows that in the presence of cointegration there must be at least one direction (unidirectional) or bidirectional. The error-correction term (ect) opens up an additional channel of Granger causality so far ignored by (the standard Granger (1969) and Sims (1972) tests. The granger causality test augmented with a lagged error-correction term (ECM) was also conducted in the final stage. If long run relationship exists among the variables specified, there must be granger causality in at least one direction (Engle and Granger, 1987).derived from the residuals of the appropriate co integration relationship to test for causality:

$$
\begin{aligned}
& \Delta \ln \left(A G P_{t}\right)=a_{1}+\sum_{i=1}^{n} b_{1 i} \Delta \ln \left(A G P_{t-i}\right)+\sum_{i=1}^{n} c_{1 i} \Delta \ln \left(G D P_{t-i}\right)+e_{1} e c t_{t-1}+u_{1 t} \rightarrow(1) \\
& \Delta \ln \left(G D P_{t}\right)=a_{2}+\sum_{i=1}^{n} b_{2 i} \Delta \ln \left(G D P_{t-i}\right)+\sum_{i=1}^{n} c_{2 i} \Delta \ln \left(A G P_{t-i}\right)+e_{2} e c t_{t-1}+u_{2 t} \rightarrow(2)
\end{aligned}
$$

where the AGPt denotes agricultural gross production at time $t$, GDPt denotes gross domestic product at time $t$ and Coefficients $\mathrm{e} 1$ and $\mathrm{e} 2$ are the adjustment coefficients while ectt- 1 and ectt-2 express the error correction term, $\Delta$ indicates first difference operator. In the second equation, the null hypothesis that 
AGDP does not Granger-cause economic output is rejected if the set of estimated coefficients on the lagged values of AGP is jointly significant. The Long run Granger causality can also be revealed through the model specified in the equations (1) and (2), with the significance of the lagged error correction term (ect) by t-test, while the short run causality with the help of F-statistics, will be taken from the significance of joint test with an application of lags of explanatory variables in the model. (Masih and Masih,1996)

\section{Data source}

The empirical analysis is conducted using annual data of GDP and agriculture production covering the period (1970 - 2012). The data used in the study are transformed to natural logarithms to minimize the variance in time series data set. The series data are denoted as In AGP (logarithm of agricultural output) and In GDP (logarithm of GDP). All data were collected from Central Bank of Libya, Research and Statistics Department Planning and Programming Department, Public Planning Council 1962-2000.

\section{RESUTS AND DISCCUSION}

The cointegration modeling procedure starts with determining the appropriate lag order (p). For this purpose, we use the Schwarz information criterion (SC), it indicated that $p=$ one is the most appropriate lag length for study model. Then, the study investigate the stationarity properties of the time series to determine whether a series is stationary or nonstationary using the modified Dickey-Fuller test know as (DF-GLS TEST) proposed by Elliott et al. (1996). The results for unit root tests on levels and first differences of the time series are summarizes in Table 2.

\section{Table (2). Univariate Statinarity Properties of the Time Series}

\begin{tabular}{ccccc}
\hline \multirow{2}{*}{ Variable } & \multicolumn{2}{c}{ DF-GLS TEST (Levels) } & \multicolumn{2}{c}{ DF-GLS TEST (First difference) } \\
& intercept & Intercept \& trend & intercept & Intercept \& trend \\
\hline AGDP & -0.415 & -0.783 & -5.830 & -6.608 \\
GDP & -0.016 & -2.127 & -2.359 & -2.593 \\
\hline
\end{tabular}

The critical values are -1.949 with intercept and -3.19 with intercept and trend, respectively.

Source: Author's estimation.

The results of Table 2 suggested that the null hypothesis of a unit root in the time series cannot be rejected at a $5 \%$ level of significant. Therefore, no time series appear to be stationary in variable levels when the test is applied on the logarithms of the data. However, when the variables are transformed into first differences they become stationary and consequently the related variables can be characterized as integrated of order I (1).

The study now proceed by defining the number of cointegration vectors between the variables, using the maximum-likelihood test procedure established by 
Johansen and Juselius (1990), Johansen (1988) and Johansen (1996). This approach tests for the number of cointegrating vectors between the two variables based on the Trace test and Max eigenvalue test we accepted hypothesis on existence of 1 cointegration equation (both tests at 1 percent significance level).

\section{Table (3). Johansen Cointegration Test Statistics}

\begin{tabular}{|c|c|c|c|c|}
\hline $\begin{array}{c}\text { Hypothesized } \\
\text { No. of CE(s) }\end{array}$ & Eigenvalue & Trace Statistics & $\begin{array}{l}5 \% \text { Critical } \\
\text { Value }\end{array}$ & Prob. ** \\
\hline None $^{*}$ & 0.332 & 16.59 & 15.89 & 0.03 \\
\hline At most 1 & 0.097 & 4.199 & 9.164 & 0.38 \\
\hline $\begin{array}{c}\text { Hypothesized } \\
\text { No. of CE(s) }\end{array}$ & Eigenvalue & $\begin{array}{c}\text { Max-Eigen } \\
\text { Statistic }\end{array}$ & $\begin{array}{l}5 \% \text { Critical } \\
\text { Value }\end{array}$ & Prob.* \\
\hline None * & 0.332 & 20.79 & 20.26 & 0.04 \\
\hline At most 1 & 0.097 & 4.199 & 9.16 & 0.38 \\
\hline
\end{tabular}

Trace test and Max-eigenvalue indicates 1 cointegration equation at the 0.05 level

*denotes rejection of the hypothesis at the 0.05 level

Source: Author's estimation.

Table 4 gives causality test results for the variables of the study. The Granger- causality conducted by the t-test suggests a unidirectional impact from GDP to agricultural production in Libya. This result, summarized in table 4, it showed weak evidence of unidirectional causation from GDP to agricultural production, where t- value for ECM term is statistically significant

Table (4). Causality Results Based on Vector Error Correction Model (VECM)

\begin{tabular}{ccc}
\hline Error Correction: & $(\operatorname{In}($ AGDP) $)$ & $(\operatorname{In}($ GDP $))$ \\
\hline ect $_{\mathrm{t}-1}$ & -0.036 & -0.089 \\
& $(-2.889)$ & $(-1.366)$ \\
$\left(\operatorname{In}\left(\mathrm{AGDP}_{\mathrm{t}-1}\right)\right)$ & 0.052 & 0.060 \\
$\left(\ln \left(\mathrm{GDP}_{\mathrm{t}-1}\right)\right)$ & {$[0.295]$} & {$[1.695]$} \\
& -0.077 & -0.077 \\
R-squared & {$[-0.434]$} & $-0.434]$ \\
Adj.R-squared & 0.477 & 0.577 \\
F-statistic & 0.373 & 0.492 \\
\hline
\end{tabular}

Source: Author's estimation.

\section{CONCLUSION}

Using annual data on Libyan agriculture production and GDP during the period (1970 to 2012), the study analyzed the time series properties of these variables in order to determine the appropriate functional form for testing the relationship between agricultural production and GDP. The study finds that GDP and agriculture production are cointegrated. Based on the VECM results, the evidence suggests strong support for long-run unidirectional causality between agriculture production and GDP. Second, the study conclude that both agriculture 
and GDP are related to past deviations (error-correction terms) from the empirical long run relationship. This implied that all variables in the system have a tendency to quickly revert back to their equilibrium relationship. The rise in GDP would have a positive influence on agricultural production in the long run. The results of this study also suggested that promoting agriculture via promotion policies will contribute to high economic growth levels in Libya.

\section{REFERRENCES}

Aljdi,A.A. and Elbeydi, K.R. (2010). The Important Factors Affecting the Libyan Agricultural Income, the twelfth international conference for crops science, Alarish-Egypt, 302-318.

Central Bank of Libya, Research and Statistics Department, Various issues.

Elliott, G., Rothenberg, T., and Stock, J. (1996). Efficient tests for an autoregressive unit root. Econometrica, 64, 813-836.

Engle, R.F.and Granger, C.W. (1987). Cointegration and Error Correction: Representation, Estimation, and Testing, Econometrica, (55), 251-276.

FAO (2011). Food Security in Libya - An Overview Working Paper, WFP/FAO Mission Eastern Libya.

FAO (2015). FAOSTAT data available at: http://faostat3.fao.org/download/Q/QC/E (accessed August, 2015).

Granger, C.W.(1969). Investigating causal relations by econometric models and eross spectral methods. Econometrica, 37(3): 424-438..

Granger, C.W. (1988). Some Recent Developments in a Concept of Causality. Journal of Econometrics 39, 199-211.

Johansen, S. (1988). Statistical Analysis of Cointegrating Vectors, Journal of Economic Dynamic and Control, 12, 231-254.

Johansen, S.(1996). Estimation and Hypothesis Testing for cointegration Vectors in Gaussian Vector Autoregressive Models"; Econometrica, 59(6), 1551-80.

Johansen, S. and Juselius, K. (1990). Maximum Likelihood Estimation and Inference on Cointegration - With Applications to the Demand for Money, Oxford Bulletin of Economics and Statistics, 52, 169-210.

Masih, R., and Masih, A. M. (1996). Macroeconomic Activity Dynamics and Granger Causality: New Evidence from a Small Developing Economy Based on a Vector Error-correction Modelling Analysis, Economic Modelling, 13, 407- 426.

Sims, C.A. (1972). Money, income, and causality, American Economic Review, 62 (4): 540-552.

Stringer, R. and Pingali, P. (2004). Special Edition on Agriculture's Contributions to Economic and Social Development Agricultural and Development Economics Division, The Food and Agriculture Organization Vol. 1, No.1,1-5

Pingali, P. (2006). Agricultural Growth and Economic Development: A View Through the Globalization Lens ,Presidential Address to the 26th International Conference of Agricultural Economists, Gold Coast, Australia.

Zapata, H.O. and Gil, J. M. (1999). Cointegration and Causality in International Agricultural Economics Research, Agricultural Economics 20, 1-9. 
الملخص العربي

\section{العلاقة السبيية بين الناتج المحلى الإجمالي والناتج الزراعي في ليبيا للفترة}

$$
(r \cdot 1 r-19 v \cdot)
$$

\section{خالد رمضان البيدي}

قسم الاقتصاد الزراعي - كلية الزراعة - جامعة طرابلس

تهدف هذه الدراسة إلى تحليل العلاقة السببية بين الناتج المحلى الإجمالي و الناتج الزراعي للاقتصاد الليبي وذلك باستخدام بيانات سنوية للفترة (1970-2012). أسلوب التكامل المشترك و نموذج تصحيح الخطأ ومنهجية السببية نم استخدامهم لتحديد العلاقة في الزمن الطويل وايجاد اتجاه السببية. و اثنارت النتائج (Granger's Causality) على وجود تكامل مشترك بين الناتج المحلي الإجمالي و الناتج الزراعي ، أي وجود علاقة نوازنيه طويلة الأجل بينهما، أما اختبار السببية فقد دلت النتائج على وجود علاقة سببية في اتجاه واحد من الناتج الإجمالي الى الناتج الزراعي. هذه النتيجة توضح الدور المهم الذى من الممكن ان يلعبه الناتج الزراعي في تحقيق معدلات نمو مناسبة للافتصاد الليبي. كلمات مفتاحيه: السببية، التكامل المشترك، الناتج المحلى الإجمالي، الناتج الزراعي، ليبيا. 